\title{
Environmental Liability in Ukraine and the EU
}

\author{
Viktor Ladychenko ${ }^{1}$, Olena Yara ${ }^{2}$, Olena Uliutina ${ }^{3}$, Liudmyla Golovko ${ }^{4}$
}

\begin{abstract}
This scholarly work examines the environmental protection legislation of Ukraine and its application in practice, aiming to identify the main challenges it faces in the context of the required harmonization of Ukrainian environmental legislation with EU law according to the Association Agreement, while also making suggestions on how to better respond to these issues. This paper also refers to the experience of EU member states in the field of environmental liability. Legal nature, content and meaning of the criminal liability of legal persons in the environmental sphere according to the law of EU member states were studied in order to determine the appropriateness and mechanism of implementation of such responsibility in Ukraine. Arguments for establishment of criminal liability of legal persons were presented.
\end{abstract}

Keywords: Environmental policy, environmental crime, environmental responsibility, adaptation of Ukrainian environmental legislation to EU standards.

\section{Disclosure of the State of Environmental Crime in Ukraine}

Current ecological situation in Ukraine has extremely negative parameters. Industrial accidents became more frequent, that have demonstrated improper situation concerning the compliance by business entities, which activity is highly hazardous, with requirements of environmental legislation and ignoring of basic safety rules (Gulac, 2019). Ecological state in Ukraine is largely determined by the existence of large-scale environmental crime, which is not reflected in official statistics. Thus, the analysis of statistical data on the state of ecological crime in Ukraine shows that its share in the overall structure of crime is about $0.3-0.5 \%$. Over the past 14 years, relative indicators of environmental crime have doubled: from 0.28 in 2002 to 0.57 in 2016 (Turlova, 2016). The most frequent types of environmental crimes include crimes in the field of plant protection, crimes in the field of wildlife protection and crimes in the field of mineral resources protection.

Ukraine is one of the European leaders in amber reserves. Ukrainian companies that have state licenses for the extraction of amber, annually extract about four tons of this mineral. However, in reality this is only a small percentage of real amber production

${ }^{1}$ Doctor of Law, Professor, Head of the Department of International Law and Comparative Law of the National University of Life and Environmental Sciences of Ukraine.

${ }^{2} \mathrm{PhD}$., professor of the Department of Administrative and Financial Law of the National University of Life and Environmental Sciences of Ukraine, Dean of the Faculty of Law of the National University of Life and Environmental Sciences of Ukraine.

${ }^{3} \mathrm{PhD}$., associate professor of the Department of Administrative and Financial Law of the National University of Life and Environmental Sciences of Ukraine, Deputy Dean of the Faculty of Law of the National University of Life and Environmental Sciences of Ukraine.

${ }^{4} \mathrm{PhD}$., associate professor of the Department of International Law and Comparative Law of the National University of Life and Environmental Sciences of Ukraine. 
in Ukraine. Up to 300 tons of amber is illegally mined annually. In fact, state bodies know about that, however, strict control is not exercised. The main reserves of amber of Ukraine are concentrated primarily in the forests on the territory of the Rivne, Zhytomyr and Volyn regions. According to the State Forestry Agency of Ukraine, 3.5 thousand hectares of forest are already damaged in this region due to the illegal mining of amber. The above situation has developed due to the fact that "black" miners do not adhere to the technology of extraction, washing out the amber stones with motor-pumps, which leads to the destruction of the drainage channels of groundwater. This leads to catastrophic consequences, i.e. complete elimination of the possibility of circulation of groundwater and as a result of microclimatic changes in these regions. Law enforcement officers conducted several inspections, seized several kilograms of illegally minded amber, opened criminal proceedings, but failed to solve the problem (Ministry of Ecology and Natural Resources of Ukraine, 2016). Now, for illegal mining of amber in Ukraine, a fine of up to 10,000 or conditional sentences are imposed.

At present none of the actions of environmental organizations or activists who stand for Ukraine's safe environment do not have the desired result. First of all, because there is no necessary environmental protection legislation and strict control over its compliance.

Implementation of the EU environmental standards is very important for Ukraine, not only because of the need to comply with the Association Agreement between Ukraine and the European Union, but also because of the urgent need for progressive reforms and improvement of the state of the environment (Ladychenko, 2019).

\section{Legal Regulation of Environmental Liability in Ukraine}

One of the reforms in the field of environmental protection should concern the institution of responsibility for environmental damage. The grounds for legal liability, types of punishment and penalties should be changed.

The institute of legal liability should fulfill the following functions: promotion of compliance with the law; full compensation for environmental damage; prevention of new violations; punishment of guilty persons. There are four classical types of legal liability: criminal, administrative, civil and disciplinary.

At the present time Ukraine's criminal legislation does not cover all environmentally hazardous activities that it should cover. For example, Ukraine is a party to the Convention on International Trade in Endangered Species of Wild Fauna and Flora imposing on state for which the present Convention has entered into force the obligation to anticipate effective penalties for such activities. However, the Criminal Code of Ukraine does not impose penalties for such actions. The Code of Ukraine on Administrative Offenses punishes the illegal trade in species of wild flora and fauna, but the maximum sanction is approximately EUR 6, which, without a doubt, is an insignificant sanction. For comparison, under Dutch criminal law, the maximum penalties in the case of a wildlife crime can include imprisonment for a maximum of 6 years, community service or a fine of EUR 81000 for individuals and EUR 810000 for corporations. In case of an offence, which is a lighter form of a criminal act than a crime, 
the maximum penalties are detention for a maximum of 1 year, community service or a fine of EUR 20250 for individuals and EUR 202500 for corporations. In addition, Dutch criminal law allows for the following sanctions: closing down a business for a certain period of time; publishing court decisions in certain magazines/newspapers; and prohibiting a convicted offender from trade in live animals or keeping live animals as pets (Directorate-General, 2016).

The disadvantage of the Ukrainian legislation is the lack of responsibility of legal entities for administrative offenses. The Code on Administrative Offenses applies only to individuals and, as a consequence, provides only for minor sanctions. Fines for environmental offenses according to the Code can be set from EUR 50 and therefore are imperceptible. In some areas, the administrative liability of legal entities is stipulated by special laws (for example, for non-payment of taxes, violation of currency and antimonopoly legislation). However, the administrative liability of legal entities for violation of environmental legislation is not provided.

The Environmental Inspection of Ukraine according to the relevant law has the right to temporarily suspend the activities of enterprises. However, this mechanism does not work, although it could be very effective in protecting the environment.

The termination of an enterprise's activity under Ukrainian law is possible only by a court decision, while the suspension of an enterprise's activity by a decision of the controlling body is a normal practice of European countries.

Methodology for calculating environmental damage is imperfect. The amount of damage in most cases is underestimated and does not cover the real costs required to restore the previous state of the environment.

In Ukraine, there are no mechanisms for using funds collected as compensation for environmental damage for the restoration of the natural object, which was harmed. At best, these funds fall into the environmental protection fund and are used for any environmental protection measures, but in any case not for compensation for the restoration of the natural object that was harmed.

The legislative framework does not stimulate offenders to lawful conduct. It is much easier for them to pay a fine. The penalty should be reviewed and should correspond to the amount of the damage. Fines should be directed at compensating damage.

\section{Positive EU Experience which should be Implemented in Ukraine}

The European Union has gradually developed its legal framework to assist in the proper application of EU environmental protection rules (Hedemann-Robinson, 2017). One of the most important EU instruments in relation to environmental crime is Directive 2008/99/EC of the European Parliament and of the Council on the protection of the environment throw criminal law (the Environmental Crime Directive). It requires EU member states to punish the listed offences with "effective, proportionate and dissuasive" criminal sanctions.

The overall objective of the Environmental Liability Directive 2004/35/EC (ELD) is to apply common, legally binding EU standards designed to reduce damage to natural resources (biodiversity, water and land). It sets an environmental liability 
framework to prevent and remedy environmental damage to pre-damage (baseline) condition when it is caused by economic operators. The ELD aims at ensuring that the financial consequences of accidents which caused environmental damage will be borne by the liable operators and not by the public authorities nor remain non-borne by anybody (Commission, Executive Summary, 2016).

In Ukraine most of the laws on economic activities provide compensation for damage due to environmental pollution, but they are not sufficient to ensure the prevention and elimination of damage caused to the environment. In Ukraine it is necessary to review fines for environmental pollution. In the sphere of industrial production the principle of "contaminated-pay" should operate effectively. At present time the system of fines in Ukraine does not prevent physical and legal persons from pollution of water objects (Yara, 2018).

In EU member states effective tools were created to notify and register environmental damage cases, through establishment of public accessible national registers of ELD incidents (e.g Poland) (Association Justice and Environment, 2015). Ukraine should use this experience.

On the example of EU member states in Ukraine national automated information system of prevention and elimination of environmental damage should be established. Information system of prevention and elimination of environmental damage should include the following information: a) type of damage caused to the environment or its direct threat, place and date of occurrence of harm or threat of its occurrence, its volume, dates of the beginning and the end of the proceedings in the case of an offense; b) full name and address of the entity; c) adopted and implemented preventive and remedial actions, including measures to mitigate environmental damage, the results of remedial action, d) the amount of spending on preventive actions and the size of spending on remedial actions: 1) incurred by entity; 2) from indemnity insurance; 3) not received from the entity with specifying the reason why they have not been received; 4) from the state budget; e) state of the environment and public bodies and organizations where is possible to get information necessary to determine the state of the environment, as well as other information on the environment, collected, stored and distributed (Ladychenko, 2017).

In Ukraine it would be also advisable to introduce the institute of environmental liability insurance, since certain consequences of accidents can have global consequences and the costs of their elimination are so large that even a profitable enterprise cannot cover them. The institute of environmental liability insurance can help resolve such cases.

As far as civil society is concerned, in the EU a combination of the evolving jurisprudence of the CJEU together with recent legislative developments have served to provide private persons with a range of rights relevant to area of enforcement of EU environmental law. The potential for civil society to become effectively engaged in supervisory tasks has not, though, yet been fully harnessed, in no small part due to the fact that a number of pieces of EU legislation intended to internalise within the EU's legal order the access to environmental justice and information provisions of the Arhus Convention have only relatively recently been adopted or are still pending legislative endorsement (Hademann-Robinson, 2015). 


\section{General Overview about the Criminal Liability of Legal Persons}

In 1978 the European Committee on Crime Problems of the Council of Europe recommended to recognize legal persons responsible for environmental crimes. In 1985 this recommendation was confirmed by the Seventh United Nations Congress on the Prevention of Crime and the Treatment of Offenders. Thus, the question of bringing of legal persons under criminal jurisdiction gained recognition on international level and in the legislation of individual states.

Supporters of establishment of criminal liability of legal persons (Faure, 2005, Funta, 2011, Gutiérrez-Fons, 2011, Langlet, 2016) support their position by those fact that damage that legal persons cause by committing some types of crimes, such as environmental crimes, often do not coincide with those sanctions that are applied to them under other types of legal liability, and with the size of the penalties that can be applied to a natural person for this type of crime. The main argument of opponents of establishment of criminal liability of legal persons (Mudrolubova, 2007) is the impossibility of coexistence with traditional domestic criminal law principles of fault and personal responsibility.

Criminal liability of legal persons does not comply with the principle of personal fault-based liability and the principle of individualization of legal responsibility and punishment. However, if we turn to the practice of foreign countries on this issues, we can see that in the law on criminal liability the institute of criminal liability of legal persons received proper consolidation. For example, in the Model Penal Code of the USA the responsibility of corporations, unincorporated associations and individuals that act or are required to act in their interest is assumed.

Sufficient number of states, which belong not only to Anglo-American legal system (US, UK, Canada), but also to continental legal system (the Netherlands, France, Denmark, Switzerland, Belgium, Romania, Slovenia, Turkey) provide a possible criminal liability of legal persons. The most common criminal sanction that can be applied to corporations is fine.

In the UK criminal liability of legal persons is identified with its governing persons, as they represent it and control activities. At the same time, a legal person cannot be responsible for the crimes which it is unable to commit, such as murder. Also it is not responsible in those cases where the punishment, such as detention, cannot be performed. French criminal code admits the liability of legal persons on a wide range of crimes, including creation of situations that are dangerous to others.

Recent changes to the Criminal Code provided for the possibility of applying criminal law measures to legal entities. However, the range of crimes for which such measures may be applied to legal entities is limited and environmental crimes are not included in this list. From our point of view, this is an omission that needs to be corrected. Legal entities can be subject to additional penalties that cannot be applied to individuals, for example, large fines; termination of the legal entity's activity. In the context of legal responsibility for environmental crimes for legal entities, it is possible to provide for the obligation to eliminate pollution, which will have a significant effect in overcoming the consequences of an environmental crime.

\section{Conclusion}


Environmental legislation of Ukraine is not sufficient to ensure the prevention and elimination of damage caused to the environment and does not establish effective system of control. Penalties for failure (improper execution) of relevant requirements are too small and do not perform their functions.

The extension of the use of the institute of environmental liability insurance is necessary. It can help to overcome the consequences of accidents which caused largescale environmental pollution. On the example of EU member states the Law "On prevention and elimination of environmental damage" should be passed, national automated information system of prevention and elimination of environmental damage should be established.

Today there is a well-developed international legal framework that includes many provisions which have mainly a recommendatory character for introducing of criminal responsibility of legal persons into national legal systems. In our opinion, if Ukraine wants to become a member of the European Union and to act in accordance with European standards, it is necessary to introduce criminal responsibility of legal persons, as did a large part of European states.

\section{References}

Association Justice and Environment. (2015). The EU Environmental Liability System. Retrieved from: http://www.justiceandenvironment.org/fileadmin/user_upload/Publications/2015/J_E_ELD_pr oposals_final.pdf

Commission Staff Working Document Executive Summary to the REFIT Evaluation of the Environmental Liability Directive Accompanying the document Report from the Commission to the European Parliament and to the Council Pursuant to Article 18(2) of Directive 2004/35/EC on environmental liability with regard to the prevention and remedying of environmental damage SWD/2016/0122 final

Directorate-General for Internal Policies. (2016). Wildlife Crime in the Netherlands. In-depth Analysis for the ENVI Committee. Retrieved from: http://www.europarl.europa.eu/RegData/etudes /IDAN/2016/578957/IPOL_IDA(2016)578957_EN.pdf

Faure, M., Heine, G. (2005) Criminal Enforcement Law in the European Union. The Hague: Kluwer Law International.

Funta, R. (2011). EU-USA Privacy Protection Legislation and the Swift Bank Data Transfer Regulation: A Short Look. Masaryk University Journal of Law and Technology, Issue 1, 23-33

Gulac, O., Dubchak, L., Iarmolenko, I., Yanchuk, J. (2019). Cooperation of Ukraine and the European Union in the ecological sector: directions and prospects. European Journal of Sustainable Development, Volume 8, № 1, 22-30

Gutiérrez-Fons, J.A., Lenaerts, K. (2011). The General System of EU Environmental Law Enforcement. Yearbook of European Law, Volume 30, № 1, 3-41

Hademann-Robinson, M. (2015). Enforcement of European Union Environmental Law: Legal Issues and Cballenges. London: Routledge.

Hedemann-Robinson, M. (2017). Environmental Inspections and the EU: Securing an Effective Role for a Supranational Union Legal Framework. Transnational Environmental Law, 6 (1), 31-58.

Ladychenko, V., Golovko, L. (2017). Implementation of European Environmental Policy in Ukraine: Problems and Prospects. European Journal of Sustainable Development, Volume 6, № 3, 333-339.

Ladychenko, V., Yara, O., Golovko, L., Serediuk, V. (2019). Groundwater management in Ukraine and the EU. European Journal of Sustainable development, Volume 8, № 1, 31-39.

Langlet D., Mahmoudi, S. (2016). EU Environmental Law and Policy. Oxford University Press. 
Ministry of Ecology and Natural Resources of Ukraine. (2016). The amount of illegal extraction of amber reaches 300 tons per year. Retrieved from: https://menr.gov.ua/news/29977.html

Mudrolubova, N. (2007). There are many ways. What is better for us? Viche, 17, 34-36.

Turlova, Yu. A. (2016). The system of environmental crimes. Uzhhorod National University Herald. Series "Law", 2 (36), 103-109.

Yara, O., Uliutina, O., Golovko, L., Andrushchenko, L. (2018). The EU Water Framework Directive: Challenges and Prospects for Implementation in Ukraine. European Journal of Sustainable development, Volume 7, № 2, 175-182. 